\title{
The Use of 2,3-dichloro-1,4-naphthaquinone for the Spectrophotometric Determination of Some Primary Aliphatic Amines in Aqueous Solution
}

\author{
Thabit S. Al-Ghabsha \\ Chemistry Department / College of Education, \\ Mosul University

\section{Usra I. Al-Neaimy} \\ College of Veterinary Medicine \\ Mosul University
}

Theia'a N. Al-Sabha

Received
$18 / 02 / 2008$
Accepted

07 / 04 / 2008

\section{الخلاصة}

تم تطوير طريقة طيفية سهلة ودقيقة للتقدير الكمي لبعض الأمينات الأليفاتية الأولية (ايثانول أمين و ن- بيوتيل أمين و ن - هكسيل أمين ). تعتمد الطريقة على التفاعل بين تلائل

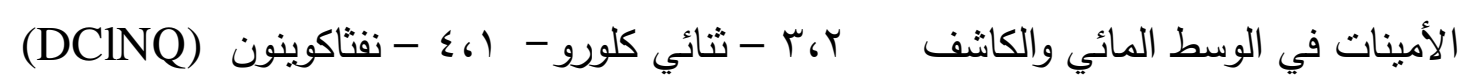

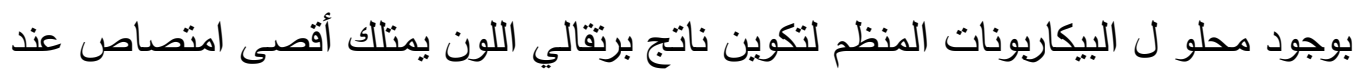

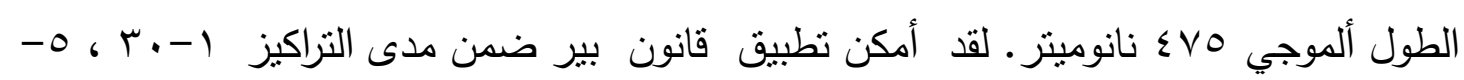

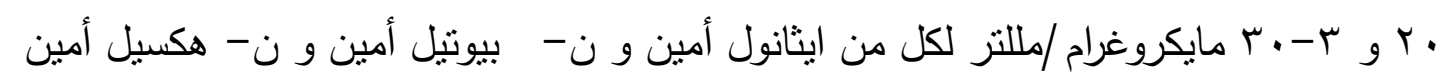

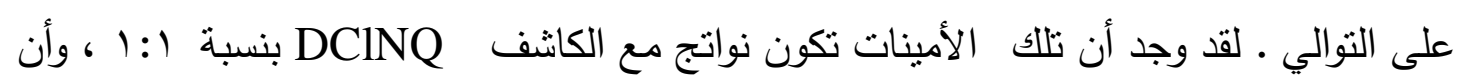

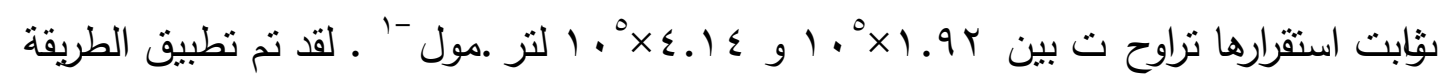
بنجاح في تقدير ايثانول أمين في مستحضره الصيد لاني.

\begin{abstract}
A simple and accurate spectrophotometric method was developed for the quantitative determination of some primary aliphatic amines in aqueous solution, i.e. ethanolamine, n-butylamine and n-hexylamine. The method is based on the interaction of these amines in aqueous medium with 2,3-dichloro-1,4-naphthaquinone (DCINQ) reagent in the presence of bicarbonate buffer solution to form an orange coloured products measurable at maximum wavelength of $475 \mathrm{~nm}$. Beer's law is obeyed over the concentration range of $1-30,5-20$ and $3-30 \mu \mathrm{g} / \mathrm{ml}$ for
\end{abstract}


ethanolamine, n-butylamine and n-hexylamine respectively. The DCINQ products were formed in the ratio of 1:1 amine: DCINQ, and their stability constants were ranged between $1.92 \times 10^{5}$ and $4.14 \times 10^{5} \mathrm{~L}_{\mathrm{mol}}{ }^{-1}$. The method was successfully applied for the determination of ethanolamine in its pharmaceutical preparation.

Keywords: DCINQ; primary aliphatic amines; aqueous medium; spectrophotometry

\section{Introduction}

Short-chain aliphatic amines are presented widely in the aquatic environment due to their wide spread use in several industrial, chemical and manufacturing applications ${ }^{(1,2)}$, Also; these amines are common components of biological systems as degradation products of organic materials such as amino acids and proteins. In addition to hygienic problems due to stinging smell, these compounds may be hazardous to human health as they are sensitizers and irritants to skin, eyes, mucus membranes and respiratory tract. Also; they can react with certain nitrogen-containing compounds to form nitrosamines, which are potentially carcinogenic substances ${ }^{(3)}$.

The charge transfer (CT) complex formation reactions have been used in the spectrophotometric determination of amines as n-donor using various $\pi$-acceptors such as p-chloranil ${ }^{(4-6)}$, p-fluoranil ${ }^{(7)}$, p-bromanil ${ }^{(8)}$ and 2,3-dichloro-5,6-dicyano-1,4-benzoquinone(DDQ $)^{(9)}$. The reaction between 1-fluoro-2,4-dinitrobenzene ${ }^{(10)}$ or 1-chloro-2,4-dinitrobenzene ${ }^{(11)}$ and aliphatic amines have also been studied. However; the above methods suffer from the selectivity for determination of primary aliphatic amines in the presence of other amines.

The goal of this study is to develop of selective spectrophotometric method for the determination of some primary aliphatic amines in the presence of aromatic primary amines, secondary and tertiary amines and other excipients with a DCINQ reagent which does not require any derivatization or catalyst but simply and rapidly reacts and forms stable colored products in addition to application of the proposed method for the determination of ethanolamine in its pharmaceutical formulation.

\section{Experimental}

\section{Apparatus}

All absorption measurements were made on a Shimadzu UV-210A double-beam spectro-photometer supplied with a digital printer DP80Z and matched $1-\mathrm{cm}$ optical silica cells. 


\section{Reagents}

All reagents used were of analytical grade and obtained from Fluka and BDH companies.

DClNQ solution $\left(2 \times 10^{-3} M\right)$ is prepared freshly by dissolving $0.0454 \mathrm{~g}$ of 2,3-dichloro-1,4-naphthaquinone in propanol $(99.8 \%)$ and diluted to the mark in $100 \mathrm{ml}$-volumetric flask with the same solvent.

Standard solutions of primary aliphatic amines $(250 \mu \mathrm{g} / \mathrm{ml})$ were prepared individually by dissolving $0.025 \mathrm{~g}$ of pure amine (ethanolamine, n-butylamine and n-hexylamine in a minimum amount of ethanol and diluted to the mark with distilled water in $100 \mathrm{ml}$-volumetric flask. These solutions were further diluted with water as needed.

Ethanolamine oleate injection(5\%) is prepared by dissolving 4.23 $\mathrm{g}$ oleic acid in $50 \mathrm{ml}$ injection water followed by addition of $0.91 \mathrm{~g}$ ethanolamine and $2 \mathrm{ml}$ benzyl alcohol with stirring until homogeneous solution was obtained.

Bicarbonate buffer solution of $\mathrm{pH}$ value 8.6 was prepared by dissolving $1.86 \mathrm{~g}$ of sodium hydrogen carbonate and $2.12 \mathrm{~g}$ of sodium carbonate in sufficient distilled water to produce $100 \mathrm{ml}$ and adjusted to $\mathrm{pH}$ 8.6, using $\mathrm{pH}$ meter, by addition few drops of $0.01 \mathrm{M}$ hydrochloric acid.

\section{Recommended procedure}

Aliquots of standard primary amine solutions of ethanolamine, $n$ butylamine and n-hexylamine were transferred separately into a series of $25 \mathrm{ml}$ calibrated flasks. To each of these were added $1.0 \mathrm{ml}$ of $2 \times 10^{-3} \mathrm{M}$ DCINQ (1.5 ml in the case of ethanolamine) followed by addition $0.5 \mathrm{ml}$ of bicarbonate buffer solution $(0.6 \mathrm{ml}$ in the case of ethanolamine) and the solutions were heated at $60^{\circ} \mathrm{C}$ for $20 \mathrm{~min}$. for n-butylamine and $\mathrm{n}$ hexylamine and $30 \mathrm{~min}$ for ethanolamine, then the solutions were cooled to room temperature and diluted to the mark with water. The absorbances of the products were measured at $475 \mathrm{~nm}$ against corresponding reagent blank.

\section{Results and discussion}

\section{Absorption spectrum}

Primary aliphatic amines are reacted with DCINQ in the presence of bicarbonate buffer solution to give an orange coloured complexes with maximum absorption spectra at $475 \mathrm{~nm}$, and their reagent blanks gave maximum absorption at $340 \mathrm{~nm}$ (Figure 1). 


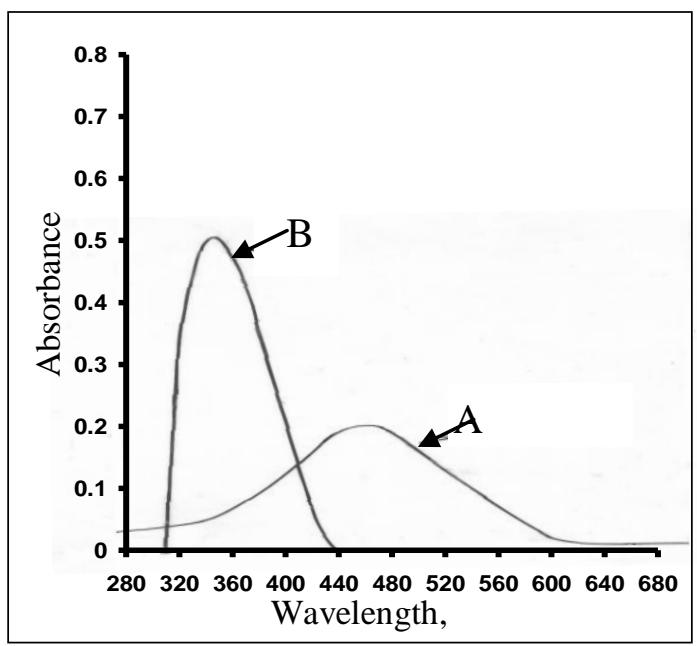

Figure 1: Absorption spectra for (A) the complex of $1.5 \mathrm{ml}$ of $2 \times 10^{-3} \mathrm{M}$ DCINQ with $10 \mu \mathrm{g} / \mathrm{ml}$ ethanolamine versus blank reagent and (B) blank versus distilled water under optimum conditions.

\section{Effect of solvent}

Various solvents such as methanol, ethanol, propanol, acetonitrile, acetone and water as medium for the reaction were examined in order to obtain high sensitivity and selectivity for determination of primary aliphatic amines, It was found that using propanol as solvent for DCINQ and water for primary aliphatic amines with dilution by water gave maximum colour intensity and high selectivity for the determination of these amines in the presence of aromatic amines, organic nitrogen compounds and other organic compounds. Therefore; this system of solvents is recommended in this method.

\section{Effect of pH and buffer solutions}

The effect of $\mathrm{pH}$ on the absorption of the products produced by the reaction of DCINQ with primary aliphatic amines was studied using different $\mathrm{pHs}$ of $\mathrm{HCl}$ and $\mathrm{NaOH}$ ranged from 2 to12. It was found that these products are formed in the final $\mathrm{pH}$ of 8.63 by addition of $\mathrm{NaOH}$ solution but the absorbance decreases after addition of $\mathrm{HCl}$ (Figure 2). Therefore different buffers of the same $\mathrm{pH}$ value were prepared by using bicarbonate, borate, phosphate and ammonia buffers to investigate the sensitivity of the amine-DCLNQ products. The results revealed that bicarbonate buffer solution $\left(\mathrm{Na}_{2} \mathrm{CO}_{3}+\mathrm{NaHCO}_{3}\right)$ gave high absorbance in comparison with other buffers,. However; the amount of bicarbonate buffer solution of $\mathrm{pH} 8.63$ was studied and $0.5 \mathrm{ml}$ was found to be optimum for n-butylamine and n-hexylamine and $0.6 \mathrm{ml}$ for ethanolamine which are recommended in the subsequent experiments. 


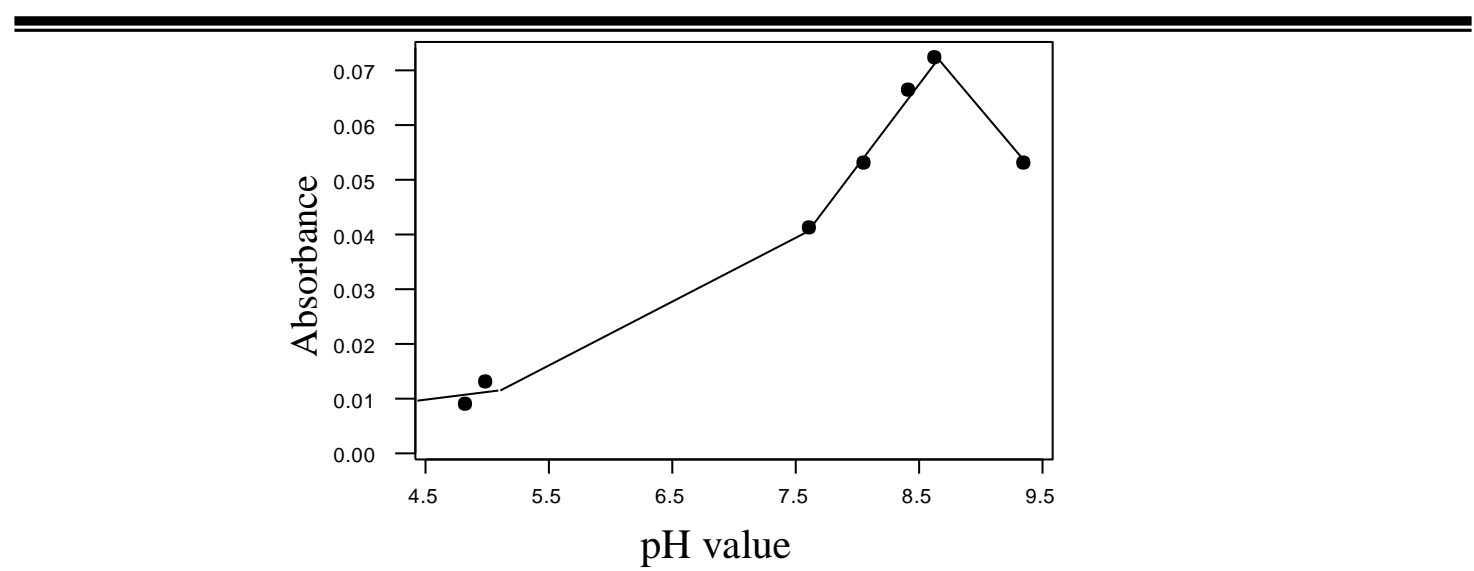

Figure 2: Effect of $\mathrm{pH}$ on the absorption of $10 \mu \mathrm{g} / \mathrm{ml}$ ethanolamine with DCINQ reagent.

\section{Effect of reaction time and temperature}

The reaction time was determined by following the colour development at room temperature and in thermostatically controlled water-bath at different temperatures. The absorbance was measured against reagent blank treated similarly at $475 \mathrm{~nm}$. It was observed that the absorbance reached maximum after addition of the reagent solutions after $10 \mathrm{~min}$ for ethanolamine and $20 \mathrm{~min}$ for n-butylamine and $\mathrm{n}$-hexylamine at $60^{\circ} \mathrm{C}$, and remain constant more than $30 \mathrm{~min}$ (40min for $\mathrm{n}$ butylamine). These temperatures and reaction time were chosen for colour development.

\section{Effect of DCINQ concentration}

The effect of different concentrations of DCINQ $(0.002,0.01,0.1$ and $1.0 \mathrm{M}$ ) dissolved in propanol on the absorbance of solution containing a fixed amount of the ethanolamine in the presence of bicarbonate buffer solution and dilution with water was studied. The results revealed the fact that $0.002 \mathrm{M}$ DCINQ gave clear solution and other concentrations cause turbidity. However; it was found that absorbance reached maximum on using $1.5 \mathrm{ml}$ for ethanolamine (Figure 3) and $1.0 \mathrm{ml}$ of $0.002 \mathrm{M}$ DCINQ for $n$-butylamine and $\mathrm{n}$-hexylamine. Therefore, these volumes were used in subsequent experiments.

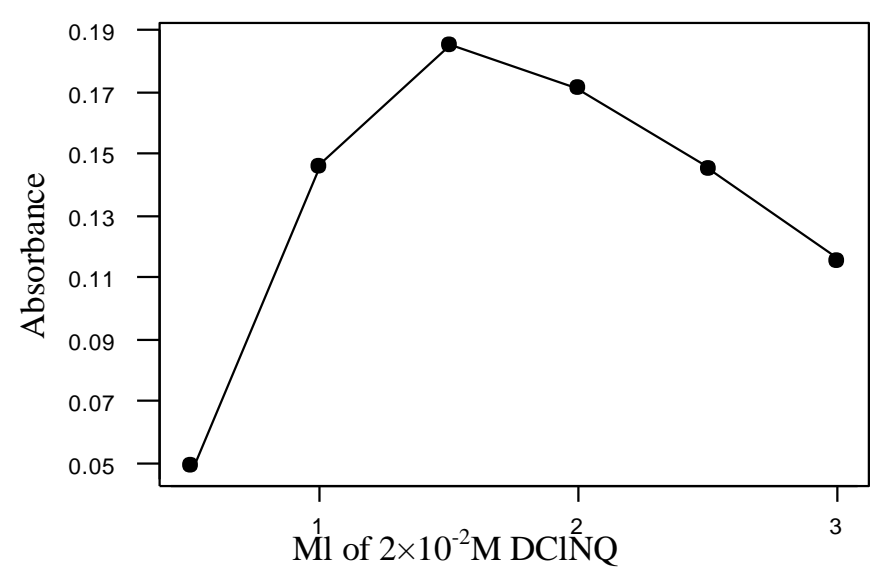

Figure 3: Effect of DCINQ amount on the absorption intensity of the reaction product of $10 \mu \mathrm{g} \mathrm{ml}^{-1}$ ethanolamine 


\section{Effect of surfactant}

Effect of various surfactants including cetavlon, cetyl perydinum chloride (CPC) and sodium dodecyl sulphate (SDS) were tested. It was found that no effect of these surfactants on the absorption of the studied amines.

\section{Effect of order of addition}

To obtain optimum results, the order of addition of reagents should be followed as given under the recommended procedure, otherwise a loss in colour intensity was observed.

However; the optimum reaction conditions for developing the colour intensity of DCINQ-aliphatic primary amine products are summarized in Table 1.

Table 1: Optimum reaction conditions of DCINQ reagent with aliphatic primary amines

\begin{tabular}{ccccccc}
\hline $\begin{array}{c}\text { Primary aliphatic } \\
\text { amine }\end{array}$ & $\begin{array}{c}\lambda_{\max } \\
(\mathrm{nm})\end{array}$ & $\begin{array}{c}\text { Temp. } \\
\left({ }^{\circ} \mathrm{C}\right)\end{array}$ & $\begin{array}{c}\text { Development } \\
\text { time }(\min .)\end{array}$ & $\begin{array}{c}\text { Stability } \\
\text { period }(\min .)\end{array}$ & $\begin{array}{c}\text { Bicarbonate } \\
\text { buffer }(\mathrm{ml})\end{array}$ & $\begin{array}{c}\text { DCINQ } \\
2 \times 10^{-3} \mathrm{M}(\mathrm{ml})\end{array}$ \\
\hline Ethanolamine & 475 & 60 & 10 & 30 & 0.6 & 1.5 \\
n-Butylamine & 475 & 60 & 20 & 40 & 0.5 & 1.0 \\
n-Hexylamine & 475 & 60 & 20 & 30 & 0.5 & 1.0 \\
\hline
\end{tabular}

\section{Quantification}

Under the experimental conditions described in Table 1, standard calibration graphs for aliphatic primary amines were constructed by plotting the absorbance versus concentration (Figure 4). The linearity ranges obeyed Beer's law and the molar absorptivities are cited in Table 2. The linearity was represented by the regression equation and the corresponding correlation coefficients for the amines determined by the proposed method, as shown in Table 2, represents excellent linearity.

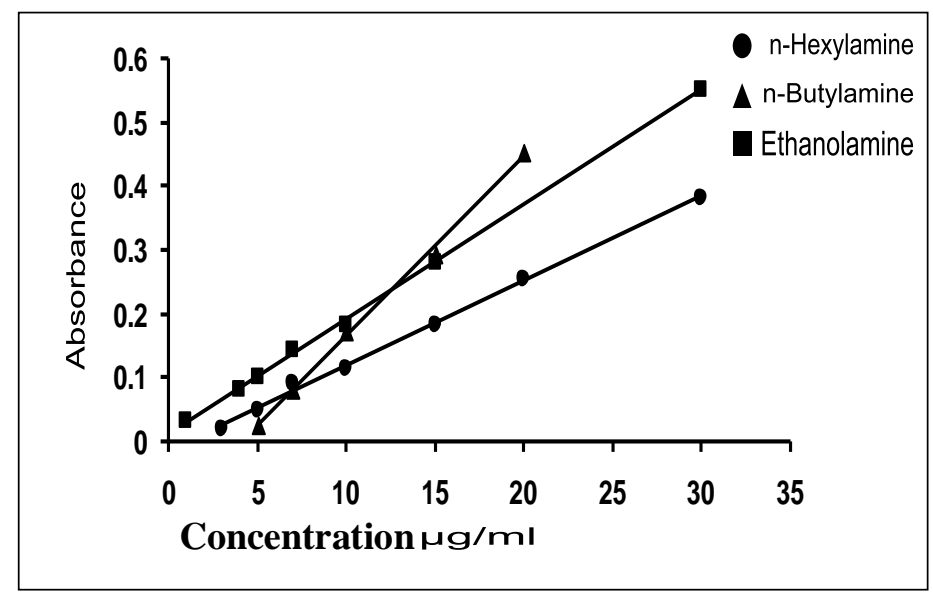

Figure 4: Calibration graphs for aliphatic primary amines 
Table 2: Summary of optical characteristics and statistics for the proposed method.

\begin{tabular}{|c|c|c|c|}
\hline \multirow[b]{2}{*}{ Parameters } & \multicolumn{3}{|c|}{ Product of DCINQ with } \\
\hline & Ethanolamine & n-Butylamine & n-Hexylamine \\
\hline Linearity range $(\mu \mathrm{g} / \mathrm{ml})$ & $1-30$ & $5-20$ & $3-30$ \\
\hline $\begin{array}{l}\text { Molar absorptivity } \\
\left(\mathrm{L} \cdot \mathrm{mol}^{-1} \cdot \mathrm{cm}^{-1}\right)\end{array}$ & $1.091 \times 10^{3}$ & $2.051 \times 10^{3}$ & $1.343 \times 10^{3}$ \\
\hline Slope & 0.0179 & 0.0281 & 0.0133 \\
\hline Correlation coefficient & 0.9992 & 0.9981 & 0.9978 \\
\hline Intercept & 0.0123 & -0.1145 & -0.01 \\
\hline
\end{tabular}

\section{Precision and accuracy}

Six replicate measurements are performed at three different concentrations of each amine. The relative standard deviation and recovery results indicated the high precision and accuracy of the proposed method (Table 3).

Table 3: Precision and accuracy of the proposed method

\begin{tabular}{|c|c|c|c|c|}
\hline Amine & $\begin{array}{c}\text { Amount } \\
\text { Added }(\mu \mathrm{g} / \mathrm{ml})\end{array}$ & $\begin{array}{c}\text { Recovery }{ }^{\#} \\
(\%)\end{array}$ & $\begin{array}{c}\text { Average } \\
\text { recovery }(\%)\end{array}$ & $\begin{array}{c}\mathrm{RSD}^{\#} \\
(\%)\end{array}$ \\
\hline \multirow{3}{*}{ n-Hexylamine } & 5 & 102.65 & \multirow{3}{*}{100.54} & 2.74 \\
\hline & 10 & 100.24 & & 1.11 \\
\hline & 20 & 98.70 & & 0.86 \\
\hline \multirow{3}{*}{ n-Butylamine } & 7 & 101.23 & \multirow{3}{*}{100.09} & 2.63 \\
\hline & 10 & 99.41 & & 0.82 \\
\hline & 15 & 99.65 & & 0.47 \\
\hline \multirow{3}{*}{ Ethanolamine } & 5 & 101.81 & \multirow{3}{*}{100.22} & 2.52 \\
\hline & 10 & 99.30 & & 1.51 \\
\hline & 20 & 99.55 & & 0.76 \\
\hline
\end{tabular}

\# Average for six determinations

\section{Interferences}

The interference of various organic nitrogen compounds including secondary, tertiary aliphatic and aromatic amines, amides, other organic and excipients compounds on the determination of $10 \mu \mathrm{g} / \mathrm{ml}$ of $\mathrm{n}$ butylamine (as example for primary aliphatic amines) were examined. It was found that these compounds did not affect the accuracy of the determination of n-butylamine, even when these compounds were present in large excess amounts compared with that of n-butylamine. The results are summarized in Table 4.

\section{Analytical application}

The proposed method has been applied for the determination of ethanolamine in synthetic ethanolamine oleate injection as pharmaceutical preparation and gave good accuracy and precision, the 
results obtained were compared favorably with the official method ${ }^{[12]}$ (Table 5). Statistical analyses of the results using the t-test at 95\% confidence level, for four freedom degrees, showed that the calculated value (1.11) did not exceed the theoretical value (2.78).

Table 4: Effect of foreign compounds on the recovery of $10 \mu \mathrm{g} / \mathrm{ml}$ n-butylamine

\begin{tabular}{|c|c|c|}
\hline Foreign compound & Fold excess added & Recovery* (\%) \\
\hline \multirow{3}{*}{ Dibutylamine } & 7 & 103.31 \\
\hline & 9 & 104.82 \\
\hline & 10 & 106.11 \\
\hline \multirow{3}{*}{ Triethylamine } & 7 & 102.96 \\
\hline & 9 & 104.01 \\
\hline & 12 & 106.33 \\
\hline \multirow{3}{*}{ Aniline } & 7 & 103.71 \\
\hline & 10 & 104.43 \\
\hline & 12 & 112.57 \\
\hline \multirow{3}{*}{ p-Anisidine } & 7 & 102.92 \\
\hline & 9 & 104.01 \\
\hline & 12 & 106.32 \\
\hline \multirow{3}{*}{ o-Tolidine } & 7 & 103.22 \\
\hline & 10 & 104.25 \\
\hline & 11 & 107.43 \\
\hline \multirow{3}{*}{ Diethanolamine } & 5 & 103.41 \\
\hline & 7 & 104.82 \\
\hline & 8 & 108.22 \\
\hline \multirow{3}{*}{ p-Aminobenzoic acid } & 8 & 100.01 \\
\hline & 9 & 104.26 \\
\hline & 10 & 107.34 \\
\hline \multirow{3}{*}{ N,N-Dimethylaniline } & 7 & 103.37 \\
\hline & 9 & 104.41 \\
\hline & 13 & 112.21 \\
\hline \multirow{3}{*}{ Acacia } & 20 & 100.21 \\
\hline & 25 & 100.61 \\
\hline & 30 & 109.53 \\
\hline \multirow{3}{*}{ Glucose } & 15 & 100.24 \\
\hline & 25 & 103.61 \\
\hline & 30 & 108.62 \\
\hline \multirow{3}{*}{ Glycerol } & 10 & 100.18 \\
\hline & 20 & 101.29 \\
\hline & 30 & 106.26 \\
\hline \multirow{3}{*}{ Oleic acid } & 5 & 102.21 \\
\hline & 6 & 104.36 \\
\hline & 7 & 108.41 \\
\hline \multirow{3}{*}{ Starch } & 7 & 101.23 \\
\hline & 8 & 103.17 \\
\hline & 9 & 110.03 \\
\hline \multirow{3}{*}{ Xylose } & 10 & 102.01 \\
\hline & 20 & 103.14 \\
\hline & 30 & 107.66 \\
\hline
\end{tabular}

*Average of three determinations. 
Thabit S. Al-Ghabsha \& Theia'a N. Al-Sabha \& Usra I. Al-Neaimy

Table 5: Determination of ethanolamine in its pharmaceutical preparation by the proposed method and comparison with the British pharmacopoeia method

\begin{tabular}{|c|c|c|c|c|c|}
\hline $\begin{array}{c}\text { Procedure } \\
\text { applied }\end{array}$ & $\begin{array}{c}\text { Pharmaceutical } \\
\text { formulation }\end{array}$ & $\begin{array}{c}\text { Drug amount } \\
\text { present( } \boldsymbol{\mu g} / \mathbf{m l})\end{array}$ & $\begin{array}{c}\text { Recovery* } \\
(\boldsymbol{\%})\end{array}$ & $\begin{array}{c}\text { Drug content } \\
\text { found (mg) }\end{array}$ & $\begin{array}{c}\text { Average } \\
(\mathbf{m g})\end{array}$ \\
\hline Proposed & Injection & 5 & 102.51 & 0.932 & \\
method & $(0.91 \mathrm{mg})^{* *}$ & 10 & 103.34 & 0.940 & 0.932 \\
\hline $\begin{array}{c}\text { British } \\
\text { Pharmacopoei } \\
\text { a method }^{(\mathbf{1 2 )})}\end{array}$ & $\begin{array}{c}\text { Injection } \\
(0.91 \mathrm{mg})^{* * *}\end{array}$ & & 101.62 & 0.924 & \\
\hline
\end{tabular}

*Average of three determinations.

** Certified value

\section{Stoichiometric Relationship}

The mole ratio of the products formed between the aliphatic primary amines and the reagent used was investigated applying the continuous variation (Job's) method ${ }^{[13]}$ using equimolar solutions $\left(2 \times 10^{-}\right.$ ${ }^{3} \mathrm{M}$ ) of the amine and DCINQ reagent. The results showed in Figure 5 (for ethanolamine as example) indicated that the product is formed in the ratio of 1:1. This may attributed that the primary amino group present in the amines is responsible for the formation of the product.

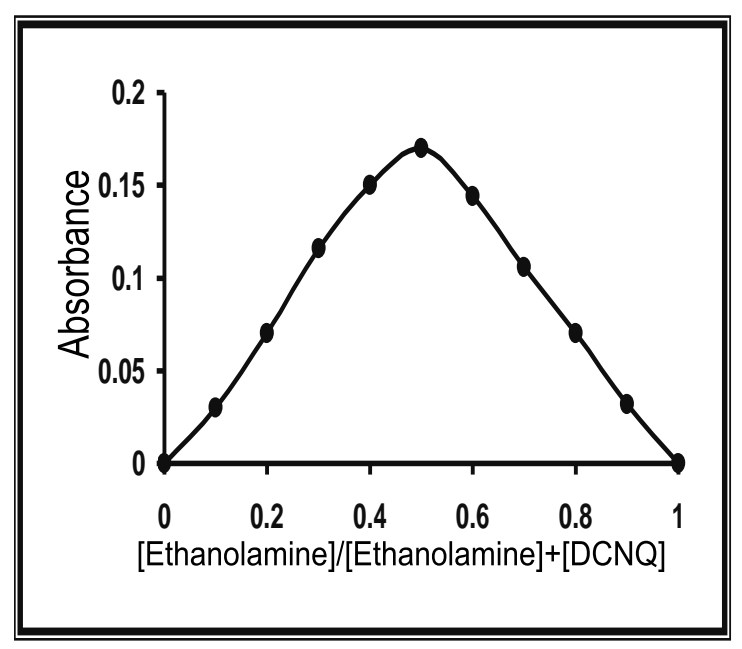

Figure 5: Continuous variation plot of ethanolamine with DCINQ reagent.

The apparent stability constant was estimated by comparing the absorbance of a solution containing stoichiometric amounts of the primary aliphatic amine and DCINQ reagent to one containing an excessive amount of DCINQ reagent. The average conditional stability constants of the products are $3.74 \times 10^{5}, 4.14 \times 10^{5}$ and $1.92 \times 10^{5} \mathrm{~L}_{\mathrm{mol}}{ }^{-1}$ for ethanolamine, n-butylamine and n-hexylamine respectively. This indicates that the products are stable. 


\section{Reaction mechanism}

On mixing the studied aliphatic primary amines with DCINQ reagent, there was an instantaneous formation of orange color with an absorption maximum centered around $475 \mathrm{~nm}$. The intensity of this band goes on slow increasing with time at room temperature. The continuous increase in absorbance at $475 \mathrm{~nm}$ at $60^{\circ} \mathrm{C}$ is indicative of formation of the final reaction product, because at this wavelength neither the acceptor nor the donor absorbs. Hence, the reaction probably appears to proceed through the initial formation of the $n-\pi$ charge transfer complex, which might be transformed into the final products ${ }^{[14-16]}$. The proposed mechanism may be shown as follows:

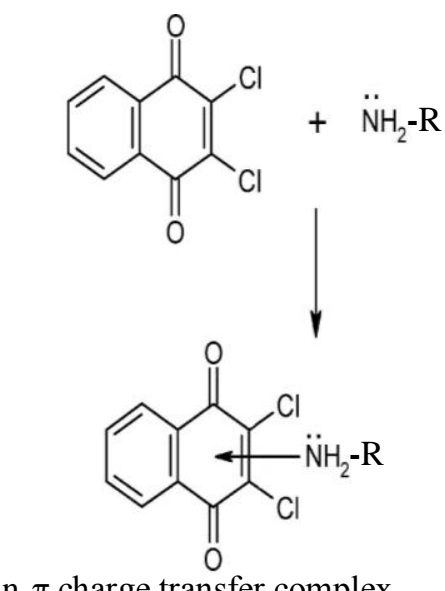

$\mathrm{n}-\pi$ charge transfer complex

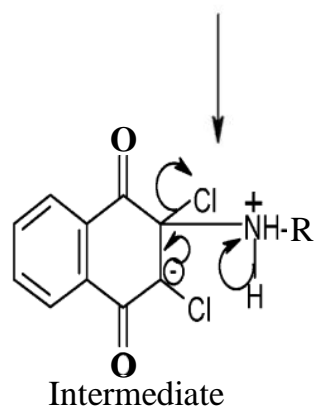

Intermediate<smiles>[3H][C@@H](C)I</smiles><smiles>[H][Y9]([H])C1=C(Cl)C(=O)c2ccccc2C1=O</smiles>

2N(alkylamino)-3-chloro-1,4-naphthoquinone

$$
\mathrm{R}=-\mathrm{C}_{2} \mathrm{H}_{4}-\mathrm{OH},-\mathrm{C}_{4} \mathrm{H}_{9},-\mathrm{C}_{6} \mathrm{H}_{13}
$$




\section{Conclusion}

The proposed method is simple, rapid, selective for the determination of aliphatic primary amines and economic compared with already reported methods and it does not require any pretreatment of the amines or extraction procedure and has a good accuracy and precision. On the other hand, in terms of sensitivity, the method could be considered superior in comparison with the titrimetric British Pharmacopoeia method and the previously reported methods, especially with those based on non-aqueous medium.

\section{References}

(1) Psillakis E., Kalogerakis N., J. Chromatogr. A, 904, 211, (2001).

(2) Belloli R., Barletta B., Bolzacchini E., Meinardi S., Orlandini M. and Rindone B., J.Chromatogr. A, 846, 277, (1999).

(3) Namiesnik J., Jastrzebska A. and Zygmust B., J. Chromatogr. A, 1016, 1, (2003).

(4) Al-Ghabsha T. S., Rahim S. A. and Townshend A., Anal. Chim. Acta, 189, 85, (1976).

(5) Al-Sabha T. N., "Spectrophotometric micro determination of some organic nitrogen compounds (amines and aldoximes) and their binary mixtures with chloranil", MSc. Thesis, Mosul University, Iraq (1984).

(6) Smith R. E., Davis W. R., Anal. Chem., 56, 2345, (1984) .

(7) Al-Ghabsha T. S., Rahim S. A. and Hanna G. K., J.Ed. and Sci., 23, 42 (1996).

(8) Al-Mtaiwti S. M., "The use of charge transfer complex formation reaction in the spectrophotometric determination of some amines and drug compounds', PhD. thesis. Mosul University, Iraq (2004).

(9) Ghabsha T. S. Al-, Rahim S. A., and Al-Sabha T. N., J.Ed. and Sci., 46, 37 (2000).

(10) Forlani L., Marianucci E. and Todesco P. E., Gazz. Chim. Ital., 122, 9349 (1992).

(11) Forlani L., J. Chem. Soc., Perkin Trans. 8, 1525 (1993).

(12) British Pharmacopoeia 2000, version 4, CD-ROM, Her Majesty's Stationery Office.

(13) Job P., "Spectrochemical Methods of Analysis"; Wiley Intersience: New York, 1971; p 346.

(14) Roy T., Datta K., Mukherjee A. K., Banerjee M. and Seal B. K., Ind. J. Chem. 37A 1007, 302 (1998).

(15) Hasani M. and Shamsipur M., J. Chem. Soc., Perkin Trans. 2, 1277 (1998).

(16) Neelgund GM., Budni ML. Spectrochim. Acta A 60, 1793 (2004). 